\title{
Effectiveness of Student Support Services Provided by Indira Gandhi National Open University (IGNOU)
}

\author{
Saba Mirja \\ IGNOU Regional Center Bhopal (India) \\ Shireesh Pal Singh \\ Center for Education, Central University of Punjab, Bathinda, (India)
}

\section{Doi:10.5901/mjss.2014.v5n26p124}

\begin{abstract}
Student Support Service is one of the key areas of which the success of any Open University depends. However, in classical mode of Open and Distance Learning (ODL) system, the most important components of evaluation are the print materials and the student support which contribute to the success or failure of a course. (Kumar \& Fozdar 2009). To provide effective and efficient student support service, IGNOU has set up a number of study centers all over the country. Students are allotted one of these study centers, taking into consideration their place of residence.Studnets usually approach theses center for getting solved their problems related to course and transition. The Regional Service Division of IGNOU is therefore giving utmost importance to various kinds of support services provided at different learner centers in the state. At Regional Centre all the unsolved problems of the study centers are taken care of and the students are given utmost freedom to approach Regional Centre functionaries for solving their problems. Most of the Regional Centers have a single window enquiry system having internet facility. Besides student queries and student problems, a lot of academic input is also being given from time to time from Regional Centre. This paper is based for knowing the strengths and weaknesses of Student Support Service provided by IGNOU and to find out difference on the basis of Gender and Demographical structure.
\end{abstract}

Keywords: Open and Distance Learning Students Support Services. Academic Satisfaction, Regional Center, Study Center

\section{Introduction}

Open and Distance learning system reaches out to the unreached via open access, open entry, open choice of subjects, flexi-time, etc. Open and Distance Learning Offers a number of advantage to learners and provides opportunities of effective learning (Amareswaran, \& Singh, 2011). In this system, learners stand at the focal point. Nevertheless, lack of day-to-day contact with the faculty as well as peer group of classmates has to be compensated. Hence, distance learning system needs an efficient, effective and organized Student Support Service. Student support service thus becomes the heart of distance learning system. This study is directed towards knowing the strengths and weaknesses of SSS provided by IGNOU. The Indira Gandhi National Open University, known as IGNOU, is a distance learning national university located at New Delhi, India. Named after Indira Gandhi, former Prime Minister of India, the university was established in 1985 when the Parliament of India passed the Indira Gandhi National Open University Act, 1985 (IGNOU Act 1985).

IGNOU has started a decentralization process by setting up five zones, viz, north, south, east, west and north east.. It has 21 schools and a network of 59 regional centers, 7 sub-regional centers, 2,600 study centers, and 52 overseas centers. Approximately $20 \%$ of all students enrolled in higher education in India are enrolled with IGNOU. It is meant to particularly benefit the disadvantaged segments of society, encourage, coordinate and set standards for distance and open education in India and strengthen the human resource of India through education. Apart from teaching and research, extension and training form the mainstay of its academic activities. Effectiveness of an institution however cannot be measured in terms of volume of subscription or area of coverage alone. Research has shown that ODL student dropout rates are typically higher than student dropout rates in conventional, face-to-face forms of higher education (Barefoot, 2004; Kember, 1995; Wojciechowski \& Palmer, 2005). Enrolment alone is no indicator of success of an institution. It is quality in all respects that encourages retention and limits attrition or dropout rate. Dropouts are fallout of students' perception of difficulty in continuing with the course. This flows from the belief that system is not responsive to their needs \& problems. The studies done in past stresses the importance of human element in learners support (Trivedi, \& Gupte 2010) 
In classical mode of Open and Distance Learning (ODL) system, the most important components of evaluation are the print materials and the student support which contribute to the success or failure of a course. (Kumar \& Fozdar 2009).Dropout studies are of major interest for distance education researchers, because high dropout is one indicator of teaching quality (DEST, 2005). In the United Kingdom, public funding for higher education is now based on the number of students who successfully complete courses (Simpson, 2005). If a large number of students fail to complete their programmes or courses, there is a possibility that ODL institutions historically reliant on public funding may face withdrawal or reduction of such funding. Among the reasons of high dropout rate, one may be that students who may have opted for ODL, expecting these programmes / courses to be easier (Carnevale, 2000); however, this is not the case. Often students' expectations are shattered when they realize that ODL courses requires the same efforts - if not more than traditional programme/ courses (Fozdar \& Kumar, 2006).

In regular traditional education, continuous teacher-taught communication forms the main contact point where exchange of knowledge takes place (Padhan \& Singh 2010). Distance education, by definition, precludes such continuity of contact. What have we then, that makes up for the loss of this vital force? In the distance model, the traditional contact is compensated by Student Support Service (SSS). It would not be wrong to say that efficiency of SSS largely decides the effectiveness of instruction by the distance mode.

\section{Student Support Service}

Student Support Service is one of the key areas of which the success of any Open University depends. This Regional Service Division of IGNOU is therefore giving utmost importance to various kinds of support services provided at different learner centers in the state. At Regional Centre all the unsolved problems of the study centers are taken care of and the students are given utmost freedom to approach Regional Centre functionaries for solving their problems. Most of the Regional Centers have a single window enquiry system having internet facility. Besides student queries and student problems, a lot of academic input is also being given from time to time from Regional Centre. The learners are facilitated through a dedicated computer having internet connection to browse through the website of IGNOU to ascertain the current status related to their admission, re-registration, material dispatch, address change, results etc. They are also provided on-line support for filling-up of the examination form, making queries on their problems, etc for quick disposal of their grievances without any additional cost. The Regional Centre has also identified certain areas on which the need based academic vocational programmes proposed to be offered suiting to the requirements of the population

To provide effective and efficient student support services, IGNOU has set up a number of study centers all over the country. Students are allotted one of these study centers, taking into consideration their place of residence. Every student may not always get a study centre of their choice. Every study centre of IGNOU has a coordinator, an assistant coordinator, supporting staff and some other staff members on part time basis. Counsellors are appointed to provide course-specific information and guidance.

IGNOU, as world leader in distance education, was conferred the Centre of Excellence Award in Distance Education in 1993 and the Award of Excellence for Distance Education Materials in 1999 by the Commonwealth of Learning (COL), Canada. It is committed to quality in teaching, research, training and extension activities and acts as national resource centre for expertise and infrastructure in the ODL system. Presently, emphasis is being laid on developing interactive multimedia and online learning, and value adding the traditional distance education delivery with modern technology enabled education (IGNOU, 2007)

\section{Objectives of this Study}

The purpose of this study is to find out the effectiveness of student support system in terms of level of satisfaction of rural and urban as well as male and female students towards headquarters, regional centre and study centre. It will also reveal the strengths and weaknesses of IGNOU service providers and help them to look into the problem faced by their clients. Major objectives of studies are as follows

a) To assess the level of satisfaction of urban students towards IGNOU HQ, Regional Centre and Study Centre

b) To assess the level of satisfaction of rural students towards IGNOU HQ, Regional Centre and Study Centre

c) To assess the level of satisfaction of male students towards IGNOU HQ, Regional Centre and Study Centre

d) To assess the level of satisfaction of female students towards IGNOU HQ, Regional Centre and Study Centre 


\section{Hypotheses}

To achieve the above stated objectives and after reviewing the related literature, the following hypotheses have been framed and tested under this study: -

1. There is no significant difference between the academic satisfaction of the urban and rural students towards IGNOU HQS.

2. There is no significant difference between the academic satisfaction of the urban and rural students towards Regional Centre.

3. There is no significant difference between the academic satisfaction of the urban and rural students towards Study Centre.

4. There is no significant difference between the academic satisfaction of the male and female students towards HQs.

5. There is no significant difference between the academic satisfaction of the male and female students towards Regional Centre.

6. There is no significant difference between the academic satisfaction of the male and female students towards Study Centre.

7. There is no significant difference between the academic satisfaction of students towards HQ and Regional Centre.

8. There is no significant difference between the academic satisfaction of students towards HQ and Study Centre.

9. There is no significant difference between the academic satisfaction of students towards Regional Centre and Study Centre.

10. Student Support Service provided by IGNOU is effective.

\section{Research Design}

The study was carried out as a 'Descriptive Research'. Unlike experimental research focusing on studying cause \& effect relationship, descriptive research is concerned with studying what exists. It interprets and explains the existence of educational phenomena. This method is concerned with surveying, describing and investigating the existing phenomena, conditions and relationships.

\subsection{Sample}

A non-probability sampling technique, the purposive convenient sampling, was employed by the researcher with a purpose to select a sample of B.Ed IInd year students of IGNOU from different districts of Madhya Pradesh.

\subsection{Tools and Techniques}

The survey was divided into three phases. In the first phase, the researcher conducted face to face interviews of the coordinators, counselors and other staff members. The interviews technique is meant for eliciting the required information from the respondents in a face to face situation. This technique may encourage the respondents to develop their own ideas, feeling, insights, expectations or attitudes. The second phase consisted of observation of B.Ed. workshop, as a non-participant member. The method of observation of a real life process was used with a view to collect authentic evidence in a natural way.

In the third phase, the researcher began with orienting the sample population of B.Ed. students by disseminating some basic information about IGNOU HQ, Regional Centre and Study Centre. The vastness of the organization, its elaborate infrastructure, various divisions and their responsibilities were explained to the students. The extent to which they had absorbed the above information, including their previous knowledge was then tested through a check-list. Thereafter, they were given a questionnaire containing 30 statements, ten each for testing their levels of satisfaction with the IGNOU Headquarters, Regional Centre Bhopal and Study Centers. Following tools used by the researchers:

1. The researcher used a structured questionnaire with open and closed questions, as a guideline for conducting face to face interviews

2. An Observation Checklist, which assisted the researcher to assess the availability of basic amenities like water, ventilation, illumination etc. 
3. An Awareness Checklist was used, to gauge previous knowledge of the sample population about IGNOU and its student support service

4. A Questionnaire containing 30 statements to be rated on a five point scale. It contained 10 statements each, related to $\mathrm{HQ}, \mathrm{RC}$ and $\mathrm{SC}$.

\subsection{Procedures of Data Collection}

Data triangulation was done to develop a comprehensive perspective of the problem. Multiple sources helped to strengthen the clarity and depth of our understanding.B.Ed. (IGNOU) $2^{\text {nd }}$ year students were approached, while they were attending $2^{\text {nd }}$ year workshop at two study centers, i.e. Career B.Ed. College Bhopal and PGBT Bhopal. Collection of data was done by separating urban and rural students. Thereafter, 40 each of rural and urban students were randomly selected. Within these groups, 40 males and 40 females were also separated. An 'Awareness Checklist' was given to students, to know their previous knowledge about responsibilities of IGNOU HQ, RC and SC. Then they were given a questionnaire to be rated on a five-point scale. Observation of the staff of Regional Centre and Study Centers was done, using an observation check-list. Face to face interviews of some of the coordinators, counsellors and staff members were also conducted to take their feedback about IGNOU and students attending the course.

\section{Analysis and Interpretation of Data}

Analysis of data helps in drawing conclusions. Qualitative data is obtained on the basis of the interviews with the staff of $\mathrm{RC}$ and SC. To make the interpretation of qualitative data reliable, the researcher has to take the advice of some experts. The quantitative data obtained on the basis of students' responses to questionnaire e analyzed with the use of simple statistics.

\subsection{Hypothesis-1}

There is no significant difference between the academic satisfaction of the urban and rural students towards IGNOU HQs.

Table 1: Academic satisfaction of the urban and rural students towards IGNOU HQs.

\begin{tabular}{|c|c|c|c|c|c|c|c|}
\hline Group & Mean & SD & SE & $\mathrm{t}($ Cal $)$ & $\begin{array}{c}\mathrm{t}(\text { Table }) \\
0.05 \text { level }\end{array}$ & $\begin{array}{c}\mathrm{t}(\text { Table }) \\
0.01 \text { level }\end{array}$ & Inference \\
\cline { 1 - 6 } Urban & 33.50 & 5.1291 & \multirow{2}{*}{1.1721} & 0.25 & 1.990 & 2.639 & Not significant \\
\hline Rural & 33.78 & 5.3517 & &
\end{tabular}

It is evident from above table that the calculated value of $t(0.25)$ is less than the critical value for $78 \mathrm{df}$ at 0.05 level (1.990) and at 0.01 level (2.639). Hence, there is no significant difference between the academic satisfaction of the urban and rural students towards IGNOU HQs.

\subsection{Hypothesis- 2}

There is no significant difference between the academic satisfaction of the urban and rural students towards RC.

Table 2: Academic satisfaction of the urban and rural students towards Regional Center.

\begin{tabular}{|c|c|c|c|c|c|c|c|}
\hline Group & Mean & SD & SE & $\mathrm{t}($ Cal) & $\begin{array}{c}\mathrm{t}(\text { Table }) \\
0.05 \text { level }\end{array}$ & $\begin{array}{c}\mathrm{t}(\text { Table }) \\
0.01 \text { level }\end{array}$ & Inference \\
\hline Urban & 31.53 & 6.3009 & \multirow{2}{*}{1.6201} & 1.23 & 1.990 & 2.639 & Not significant \\
\hline Rural & 33.53 & 8.0797 & & &
\end{tabular}

It is evident from the above table that the calculated value of $t(1.23)$ is less than the critical value for $78 \mathrm{df}$ at 0.05 level (1.990) and at 0.01 level (2.639). Hence, there is no significant difference between the academic satisfaction of the urban and rural students towards Regional Center. 


\subsection{Hypothesis- 3}

There is no significant difference between the academic satisfaction of the urban and rural students towards Study Centre

Table 3: Academic satisfaction of the urban and rural students towards Study Centre

\begin{tabular}{|c|c|c|c|c|c|c|c|}
\hline Group & Mean & SD & SE & $t$ (Cal) & $\begin{array}{c}\mathrm{t} \text { (Table) } \\
0.05 \text { level }\end{array}$ & $\begin{array}{c}\mathrm{t} \text { (Table) } \\
0.01 \text { level }\end{array}$ & Inference \\
\cline { 1 - 7 } Urban & 41.93 & 4.9219 & \multirow{2}{*}{1.2691} & 1.06 & 1.990 & 2.639 & Not significant \\
\hline Rural & 40.58 & 6.3403 & &
\end{tabular}

It is evident from the above table that the calculated value of $t(1.06)$ is less than the critical value for $78 \mathrm{df}$ at 0.05 level (1.990) and at 0.01 level (2.639). Hence, there is no significant difference between the academic satisfaction of the urban and rural students towards Study Center.

Figure 1: Academic satisfaction of the urban and rural students towards HQ, Regional Center and Study Centre

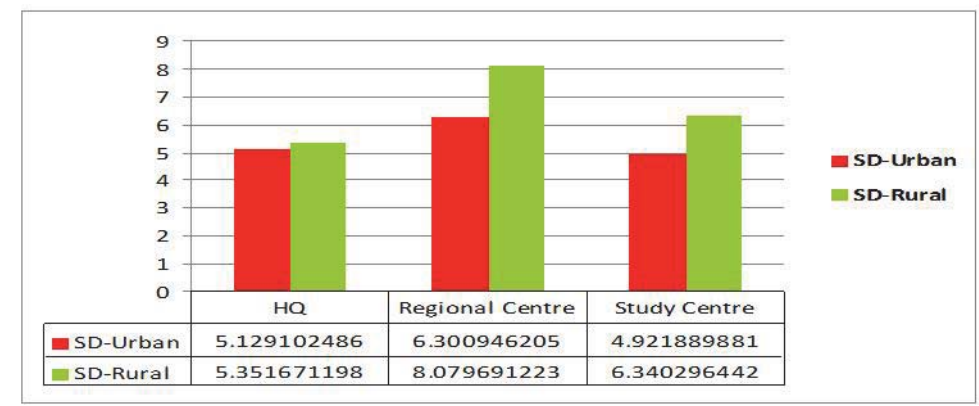

\subsection{Hypothesis 4}

There is a significant difference between the academic satisfaction of the male and female students towards HQs.

Table 4: Academic satisfaction of the male and female students towards HQs.

\begin{tabular}{|c|c|c|c|c|c|c|c|}
\hline Group & Mean & SD & SE & $\mathrm{t}($ Cal) & $\begin{array}{c}\mathrm{t}(\text { Table) } \\
0.05 \text { level }\end{array}$ & $\begin{array}{c}\mathrm{t}(\text { Table }) \\
0.01 \text { level }\end{array}$ & Inference \\
\hline Male & 32.95 & 4.6296 & \multirow{2}{*}{1.1282} & 0.43 & 1.990 & 2.639 & Not significant \\
\hline Female & 33.43 & 5.4297 & & & & \\
\hline
\end{tabular}

It is evident from the above table that the calculated value of $t(0.43)$ is less than the critical value for $78 \mathrm{df}$ at 0.05 level (1.990) and at 0.01 level (2.639). Hence, there is no significant difference between the academic satisfaction of the male and female students towards $\mathrm{HQ}$.

\subsection{Hypothesis- 5}

There is a significant difference between the academic satisfaction of the male and female students towards Regional Center.

Table 5: Academic satisfaction of the male and female students towards Regional Center.

\begin{tabular}{|c|c|c|c|c|c|c|c|}
\hline Group & Mean & SD & SE & $\mathrm{t}($ Cal) & $\begin{array}{c}\mathrm{t}(\text { Table }) \\
0.05 \text { level }\end{array}$ & $\begin{array}{c}\mathrm{t}(\text { Table }) \\
0.01 \text { level }\end{array}$ & Inference \\
\cline { 1 - 6 } Male & 33.03 & 7.8036 & \multirow{2}{*}{1.6367} & 0.98 & 1.990 & 2.639 & Not significant \\
\hline Female & 31.43 & 6.8008 & &
\end{tabular}


It is evident from the above table that the calculated value of $t(0.98)$ is less than the critical value for $78 \mathrm{df}$ at 0.05 level (1.990) and at 0.01 level (2.639). Hence, there is no significant difference between the academic satisfaction of the male and female students towards RC.

\subsection{Hypothesis 6}

There is a significant difference between the academic satisfaction of the male and female students towards SC.

Table 6: Academic satisfaction of the male and female students towards SC.

\begin{tabular}{|c|c|c|c|c|c|c|c|}
\hline Group & Mean & SD & SE & $t($ Cal $)$ & $\begin{array}{c}t(\text { Table }) \\
0.05 \text { level }\end{array}$ & $\begin{array}{c}t(\text { Table }) \\
0.01 \text { level }\end{array}$ & Inference \\
\cline { 1 - 3 } Male & 40.75 & 6.6824 & \multirow{2}{*}{1.2820} & 0.43 & 1.990 & 2.639 & Not significant \\
\hline Female & 41.30 & 4.5921 & &
\end{tabular}

It is evident from the above table that the calculated value of $t(0.43)$ is less than the critical value for $78 \mathrm{df}$ at 0.05 level (1.990) and at 0.01 level (2.639). Hence, there is no significant difference between the academic satisfaction of the male and female students towards SC.

Figure 2: Academic satisfaction of the male and female students towards H.Q., Regional Center and Study Center

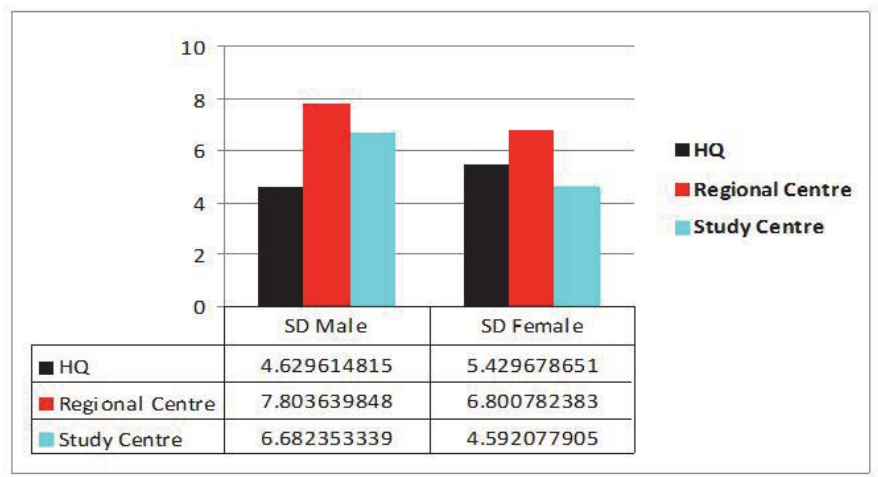

\subsection{Hypothesis 7}

There is no significant difference between the academic satisfaction of students towards HQ and RC.

Table 7: Academic satisfaction of students towards HQ and RC

\begin{tabular}{|c|c|c|c|c|c|c|c|}
\hline Group & Mean & SD & SE & $\mathrm{t}(\mathrm{Cal})$ & $\begin{array}{c}\mathrm{t}(\text { Table }) \\
0.05 \text { level }\end{array}$ & $\begin{array}{c}\mathrm{t}(\text { Table }) \\
0.01 \text { level }\end{array}$ & Inference \\
\hline $\mathrm{HQ}$ & 33.64 & 5.2101 & \multirow{2}{*}{1.0341} & \multirow{2}{*}{1.31} & \multirow{2}{*}{1.98} & \multirow{2}{*}{2.62} & \multirow{2}{*}{ Not significant } \\
\hline $\mathrm{RC}$ & 32.33 & 7.2997 & & & & & \\
\hline
\end{tabular}

It is evident from the above table that the calculated value of $\mathrm{t}(1.31)$ is less than the critical value for $158 \mathrm{df}$ at 0.05 level (1.98) and at 0.01 level (2.62). Hence, there is no significant difference in the academic satisfaction of students towards $\mathrm{HQ}$ and $\mathrm{RC}$.

\subsection{Hypothesis 8}

There is no significant difference between the academic satisfaction of students towards HQ and SC. 
Table 8: Academic satisfaction of students towards HQ and SC

\begin{tabular}{|c|c|c|c|c|c|c|c|}
\hline Group & Mean & SD & SE & $\mathrm{t}($ Cal $)$ & $\begin{array}{c}\mathrm{t}(\text { Table }) \\
0.05 \text { level }\end{array}$ & $\begin{array}{c}\mathrm{t}(\text { Table }) \\
0.01 \text { level }\end{array}$ & Inference \\
\cline { 1 - 3 } $\mathrm{HQ}$ & 33.64 & 5.2101 & \multirow{2}{*}{0.8618} & 8.83 & 1.98 & 2.62 & Not significant \\
\hline SC & 41.25 & 5.6803 & & &
\end{tabular}

It is evident from the above table that the calculated value of $t(8.83)$ is more than the critical value for $158 \mathrm{df}$ at 0.05 level (1.98) and at 0.01 level (2.62). Hence, there is a significant difference in the academic satisfaction of students towards $\mathrm{HQ}$ and SC.

\subsection{Hypothesis 9}

There is no significant difference between the academic satisfaction of students towards RC and SC.

Table 9: Academic satisfaction of students towards RC and SC

\begin{tabular}{|c|c|c|c|c|c|c|c|}
\hline Group & Mean & SD & SE & $\mathrm{t}($ Cal) & $\begin{array}{c}\mathrm{t}(\text { Table }) \\
0.05 \text { level }\end{array}$ & $\begin{array}{c}\mathrm{t}(\text { Table }) \\
0.01 \text { level }\end{array}$ & Inference \\
\hline RC & 32.33 & 7.2997 & \multirow{2}{*}{1.0341} & 8.63 & 1.98 & 2.62 & Not significant \\
\hline SC & 41.25 & 5.6803 & & & 2.62 & \\
\hline
\end{tabular}

It is evident from the above table that the calculated value of $t(8.63)$ is more than the critical value for $78 \mathrm{df}$ at 0.05 level (1.98) and at 0.01 level (2.62). Hence, there is a significant difference in the academic satisfaction of students towards $\mathrm{RC}$ and $\mathrm{SC}$.

\section{Figure 3:}

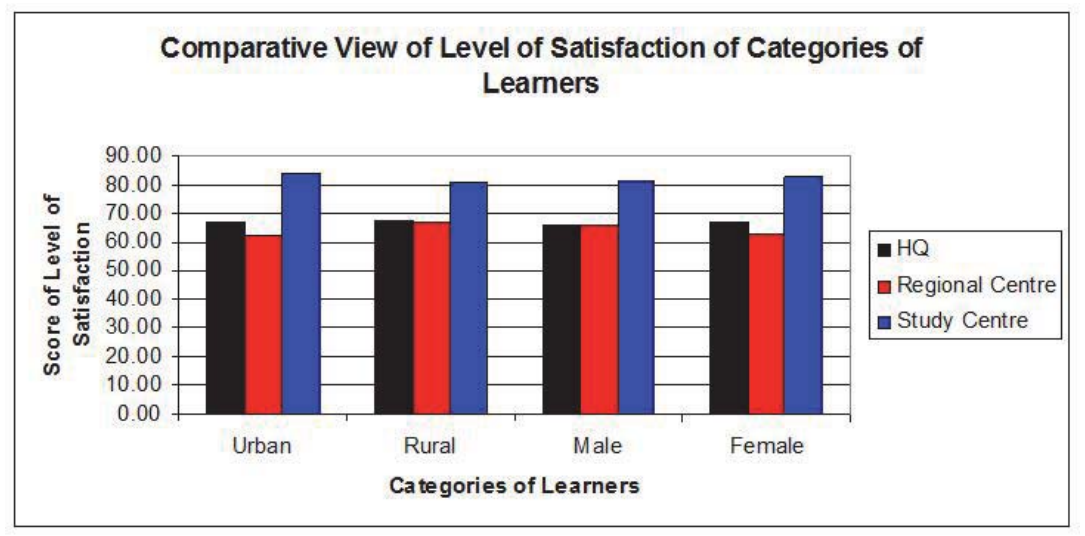

\subsection{Hypothesis 10 - Student Support Service provided by IGNOU is effective.}

By observation, face to face interviews and survey, it was found that the SSS provided by IGNOU is generally effective. Interviews with staff of Regional Centre, Study Centre and students indicated that there is adequate coordination among them. Question-wise analysis was also done in order to know the overall feedback of learners.

\section{Discussion of Result}

Keeping in mind the inferences of hypotheses and findings of the study, it was observed that the student support service provided by IGNOU is generally satisfactory. As far as demographic background of learners is concerned, it does not seem to correlate strongly with level of their satisfaction with various aspects of student support service. It was found that all categories of learners are more satisfied with Study Centers, as compared to HQ or Regional Centre. Students who 
were well versed with computer knowledge and perceived distance education as useful and flexible mode of learning, were found satisfied with distance learning in general (Ismail Sahin 2008)

\section{Implication and Conclusions of the Study}

There is always room for further improvement in the quality of any institution. In the scenario of globalization and modernization, learners are facing new challenges at every step. Educational institutions are responsible for giving quality education to update and prepare them to cope with new problems. The vast set up of IGNOU is itself a remarkable asset for a developing country. Efficient Student Support Service is an important prerequisite for the success of this vast and diverse institution. It is the bridge between the learner and the institution. An efficient SSS would reach its learner sitting at the remotest place. It requires a stronger ICT base, more frequent and user friendly tele-conferencing, telecounselling and a prompt help-cell to address various problems of learners. IGNOU is providing all the above facilities. However, there are many areas that need attention and improvement.

- The scope of study material should be widened by provision of a well equipped library having relevant reading material \& journals.

- Old study material needs updating to include new developments and should incorporate glossaries to understand difficult terminology.

- Timely delivery of study material is vital for learners to complete their assignments well before given date.

- Effective SSS can only be launched from the base of good coordination among HQ, RC and SC, to solve learners' problems.

- Workshops should be based more on transaction of practical rather than theoretical aspects, to help studentteachers develop competencies \& skills required for teaching.

\section{References}

Allen, I.E. and Seaman, J. (2007). Online nation: Five years of growth in online learning, Needlam, MA: Sloan. Bland, K. P., G. R. Morrison, and S. M. Ross. (1992). Student attitudes toward learning link: A distance education project. ERIC Document Reproduction Service ED 356766.

Amareswaran, N., \& Singh, S. P. (2011). Teacher Education through Open and Distance Learning--Information and Communication Technology Based Pedagogy Integration. TechnoLEARN: an International Journal of Educational Technology, 1(1) http://indianjournals.com/ijor.aspx?target=ijor:tle\&volume=1\&issue=1\&article=005

Annual Reports (1998-99 to 2002-03). Indira Gandhi National Open University. IGNOU Press: New Delhi.

Bland, K. P., G. R. Morrison, and S. M. Ross. (1992). Student attitudes toward learning link: A distance education project. ERIC Document Reproduction Service ED 356766.

Chambers, E. (2006). Literature pedagogy for distance education: A socio-cultural approach. The International Conference on Literary Studies in Open and Distance Learning University Programs, Retrieved June 25, 2008, from http://www.openlit.gr/proceedings/Chambers_Ellie.pdf.

Cookson, P. (1989). Research on Learners and Learning in Distance Education: A review. The American Journal of Distance Education, $3(2), 22-34$.

Crellin, I.R. (2000) Open learning for the survival and prosperity of rural communities- a case of Australia, Queens Land, Learning Network, pp.3-8.

Daniel, J. (2002). Why research distance learning? Keynote address delivered at CRIDALA Conference held at Hong Kong Open University, Hong Kong during June 5-7. Hong Kong: HKOU

Deans, C. (1998). The distance education student. Retrieved October 15, 2002, from http://seamonkey.ed.asu.edu/ mcisaac/disted/week2/ 8focuscd.html

Dubios J. (2003). Major issues in distance learning. Working Connections. IT Faculty Development Institute. [Presentation].

Frimpong-Kwapong 0.a.t (2007), widening access to tertiary education for women in Ghana through distance education. Turkish Online Journal of Distance Education-TOJDE October 2007 ISSN 1302-6488 Volume: 8 Number: 4 Article.

Gagne. M., and Shepherd, M. (2001). A Comparison between a Distance and a Traditional Graduate Accounting Class Link: http://thejournal.com/Articles/2001/04/01/A-Comparison-Between-a-Distance-and-a-Traditional-Graduate-AccountingClass.aspx?p=1

Gupte, K.S. (2009). Some reflections on learner support for distance learners: Feedback from the field. Asian Journal of Distance Education, 7 (1), 71-83.

Hagel, P., \& Shaw, R. N. (2006). Students' perceptions of study modes. Distance Education, 27 (3), 283-302. Hannay, M. and Newvine, T (2006). Perceptions of Distance Learning: A Comparison of On-line and Traditional Learning. MERLOT Journal of Online Learning and Teaching / Vol. 2 / No. 1.

Jung, I. S., \& Latchem, C. (2007). Assuring quality in Asian open and distance learning. Open Learning, 22(3), 235-250. 
Khan, A.W. and H.P. Dikshit (2006)Emergence of distance education media network, in Garg, suresh et..al. (Eds) Four Decades of Distance Education in India: Reflections on Policy and Practice, New Delhi, Viva Books Pvt.

Levin, T., and Wadmany, R. (2006). Listening to students' voices on learning with information technologies in a rich technology-based classroom. Journal of Educational Computing Research, 34 (3), 281-317.

Liao, L. (2006). A flow theory perspective on learner motivation and behavior in distance education. Distance Education, 27 (1), 45-62.

Maor, D. (2003). The teacher's role in developing interaction and reflection in an online learning community. Computer Mediated Communication, 40 (1/2), 127-137.

Mehrotra. D. (2009). Applying total quality management in academics. Retrieved December 3, 2009, from http://www.isigma.com

Mitchell, T. J. F., Chen, S. Y., \& Macredie, R. D. (2005). The relationship between web enjoyment and student perceptions and learning using a web-based tutorial. Learning, Media and Technology, 30 (1), 27-40.4

NCTE (2006). Statistics on Tertiary Education in Ghana: Ministry of Education.

Panda, S., Khan, A.R., \& and Garg, S. (1999). Growth and development of the national open university. In S. Panda (Ed.), Policies, practices \& quality concerns. New Delhi : Aravalli Books International.

Padhan, A., \& Singh, Shireesh Pal (2010). Culminating Professional Ethics to Reduce ZPD Gaps in Teacher Education. Learning Community: An International Journal of Education \& Social Development, 1(1). http://www.indianjournals.com lijor.aspx?target=ijor:Ico\&volume=1\&issue=1\&article=008

Pandey, Sanjeev and Masood Parveez. (2005), 'Monitoring learner support services', in Garg, suresh et..al. (Eds) Four Decades of Distance Education in India: Reflections on Policy and Practice, New Delhi, Viva Books Pvt.

Reddy, Narsi and Murali, Manohar K (1998) 'Media support and staff development issues in distance education, Warangal,: IDEA, pp 7589.

Singh, Shireesh Pal., \& Dangwal, Kiranlata. (2011). Innovative Practices in Education. New Delhi.N D Publishers.,p.23

Singh, Shireesh Pal., \& Dangwal, Kiranlata. (2011). Innovative Learning Strategies. New Delhi. A P H Publication.,p.154

Sahin, I., \& Shelley, M. (2008). Considering Students' Perceptions: The Distance education Student Satisfaction Model. Educational Technology \& Society, 11(3), 216-223.

Simmons, I. V. 1991. Survey of students' attitudes toward the IHETS delivery system. ERIC Document Reproduction Service ED 330 311. Link: http://www.eric.ed.gov/ERICDocs/data/ericdocs2sql/contentstorage01/ 0000019b/80/22/d9/db.pdf 